\title{
KETENTUAN HUKUM-HUKUM TUHAN
}

\author{
Oleh: Ali Geno Berutu
}

Dalam benak pemikiran orang-orang non-Muslim yang hidup di Eropa dan Amerika Utara, Kata Syari'ah hampir selalu dikaitkan dengan image yang menakutkan dan mengerikan, misalnya hukum rajam, potong tangan atau deraan. Akan tetapi semestinya sekarang-sekarang sudah jelas bahwa hal tersebut hanya merupakan salah tafsir saja. Karena syaria'ah sebenarnya mencakup semua sistem yang mengatur segala tatanan kehidupan ini, mulai dari tingkah laku kehidupan manusia atau cara-cara menjalankan ritual peribadatan sampai hubungan internasional. Namun demikian, karena model hukum dalam Islam nampaknya terlalu keras menurut anggapan orang-orang barat, maka hal tersebut sangat tepat bila dibicarakan lebih lanjut disini.

Dalam hukum Islam dibedakan antara pertama hukum hudud yang berdasarkan pada al-Qur'an dan as-Sunnah yang tata caranya telah ditetapkan dan diatur oleh Allah, kedua adalah hukum ta'zirat, yaitu suatu hukum yang masih ada kebijaksanaan-kebijaksanaan tertentu dalam melaksanakannya. Hukum hudud misalnya: hukuman bagi orang yang telah mencuri maka tangannya harus dipotong, bagi orang yang berzina, hukumannya 100 kali deraan, bagi pelacur hukumannya dirajam sampai mati, memfitnah didera sebanyak 80 kali deraan, minum-minuman keras didera 40 kali deraan menurut Imam Syafi'i sedangkan menurut aliran mazhab lain didera sebanyak 80 kali deraan. Untuk perampokan dan eksekusi maka hukumannya dipotong sebelah lengan dan kakinya atau diasingkan ketempat yang jauh. Akan tetapi semua itu semua itu tergantung keseriusan dari tindakan kejahatan yang dilakukan. Hukuman bagi pencuri, pemfitnah dan pejina telah ditetapkan secara jelas dalam al-Qur'an antara lain (QS.[5]:38;[24]:2; dan [24]:4). Hukuman bagi rampok diatur dalam alQur'an (QS.[5]:33), akan tetapi hal ini bisa ditolerir karena ayat yang mengatur tentang hal ini bukanlah suatu perintah resmi tetapi agaknya hanya sebagai suatu gambaran bagi orangorang yang kafir pada saat nabi masih hidup. Al-Qur'an menjelaskan agar orang-orang yang beriman menjauhi minnuman keras (QS.[5]:90) akan tetapi tidak mengatur ketetapan tentang pemukulan terhadap pemabuk. Hukuman yang besifat parsial ini dilaksanakan pertama kali pada masa khalifah Umar bin Khattab. Khalifah kedua ini juga melaksanakan hukumanhukuman tersebut yang antara lain adalah merazam orang yang telah melakukan perzinaan, meskipun sebenarnya menurut dugaan orang, beliau tidak berpegang teguh terhadap alQur'an yang telah mengatur hal tersebut.

Pada masyarakat Islam tradisional, hukuman hudud jarang diterpkan. Keberadaannya hanya bersifat teori saja yang kemungkinan berfungsi sebagai pencegah dan peringatan yang dipandang sebagai kejahatan anti sosial. Akan tetapi karena nabi menegaskan bahwa pelaksanaannya harus dicegah walaupun dalam keadaan ragu-ragu, ahli hukum Muslim meletakkan hal itu secara teliti untuk pelaksanaanya.

Pada abad ke-19, sebagian besar negara Islam takluk terhadap pengaruh-pengaruh Eropa sehingga membuat akibat lebih buruk terhadap hukum-hukum Islam yang telah diterapkan. Pemerintah Utsmani telah membawa sebuah bentuk pemerintahan baru yang sah. Termasuk penghapusan hukum-hukum hudud dan menggantikannya dengan hukum-hukum Prancis, kemudian mengubah kewajiban-kewajiban yang terdapat dalam Mazhab Hanafi menjadi hukum yang bersifat sekuler. Negara-negara yang dijajah oleh Eropa mempunyai perkembangan yang hampir sama. Dasar-dasar hukum negara Inggris, Prancis dan Belanda 
dikenalkan dan membatasi ruang gerak hukum Islam. Apabila kemudian peraturan-peraturan yang ada dalam hukum Islam disederhanakan sedemikian rupa sehingga bisa dipahami dan kemudian juga diperkuat oleh administrator negara Eropa dengan tidak menoleh kepada sumber hukum lama. Sementara itu tokoh-tokoh modernis seperti Sayyid Ahmad Khan dari India dan Muhammad Abduh dari Mesir meminta ijtihad yang telah diabaikan, dihidupkan kembali.

Pada akhir masa penjajahan, mayoritas negara Islam telah mewarisi atau mengadopsi campuran hukum yang berlaku di negara Eropa. Sebagai negara yang menggunakan hukum campuran ini menamakan hukum mereka dengan demokrasi, seperti negara Turki, Pakistan dan negara Banglades, sedangkan sistem monarki absolut berlaku di negara Maroko. Diktator sosialis meliputi negara Mesir, Irak dan Syiria. Sehingga dari berbagai contoh di tersebut di atas dikatakan bahwa pemerintah-pemerintah Islam berada dibawah tekanan orang-orang non-Islam yang ingin menjatuhkan Islam. Kadang-kadang masalah ini menuju kearah Islamisasi, seperti pada tahun 1883 saat presiden Nimeiri dari Sudan memperkenalkan hukum hudud tanpa disertai dengan observasi terlebih dahulu tentang perlindungan tradisional. Selain itu negara Pakistan telah memiliki suatu pendekatan yang secara berangsur-angssur menuju kearah terciptanya kesesuaian hukum dengan syri'at Islam.

Berdasarkan sejarah, pengikut Mazhab Hanafi lebih berpengalaman dalam memegang pemerintahan dari pada pengikut mazhab Hambali atau aliran Syi'ah. Kemudian pengikut mazhab Hanafi telah mengembangkan suatu jaringan kerja yang banyak, baik dan seimbang. Hubungan dengan hal tersebut Pakistan juga mempunyai model yang lebih baik kaitannya dengan Islamisasi dari pada Saudi Arabia atau Iran. Pengenalan kembali Syari'at Islam setelah penjajahan berehenti merupakan suatu tindakan yang hebat, apa lagi ketik ijtihad diberi kebebasan. Jika saja dunia Islam tidak dijajah oleh orang-orang Eropa, maka hukum Islampun munngkin hanya berkembang selangkah dimasyarakat. Sampai saat itu Islamisasi hampir tidak dapat dihindarkan seperti halnya usaha untuk meletakkan jarum-jarum jam. Meskipun demikian sangat sedikit ummat Islam yang terbuka berani menanyakan apakah dengan kembali ke syari'at Islam mmerupakan kehendak hati nurani. Seperti yang telah dilakukan Fazlur Rahman (w.1986) dan Mahmud Muhammad Thaha (w.1988). Rahman mengatakan bahwa meskipun tuntutan moral al-Qur'an harus dilaksanakan secara mutlak akan tetapi aturan-aturan yang terkandung didalamnya tersususn berdasarkan sejarah. Sementara itu Thaha mengatakan bahawa pesan-pesan yang terkandung dalam al-Qur'an telah diabaikan oleh orang-orang Mekkah, akan tetapi perundang-undangan yang berlaku di Madinah dimaksudkan untuk menunjukkan sejaran dan geografi. Beberapa pandangan yang jelekpun akhirnya tertuju pada kaum tradisional dan tokoh-tokoh Islam. Walaupun begitu mereka sering mempunyai usulan yang akhirnya bisa dipertimbangkan bagi perbaikan kehidupan ummat Islam yang keadaannya minoritas.

\section{Sumber Bacaan:}

Neal Robinson, Ph.D, Pengantar Islam Komprehennsif, Yogyakarta: Fajar Pustaka Baru 2001 